\title{
Negation Indicator
}

National Cancer Institute

\section{Source}

National Cancer Institute. Negation Indicator. NCI Thesaurus. Code C102861.

Specifies whether an activity did not occur. 